\title{
Appendix Duplication Accompanied by Acute Appendicitis
}

\section{Akut Apandisitin Eşlik Ettiği Apendiks Duplikasyonu}

\author{
(1) Uğur Topal1, () Figen Doran2, (ㅅ Ahmet Rencüzoğulları1 \\ ${ }^{1}$ Çukurova University Faculty of Medicine, Department of General Surgery, Adana, Turkey \\ ${ }^{2}$ Çukurova University Faculty of Medicine, Department of Pathology, Adana, Turkey
}

\section{HIIIIII ABSTRACT}

Acute appendicitis is the most common non-traumatic emergency surgical pathology, and duplication of the appendix is a rare congenital anomaly usually detected incidentally during laparotomy. Since Picoli first described appendix duplex in a female patient who presented with associated anomalies, few other cases have been reported. In this study, we aimed to present a case of appendix duplication detected in a 56-year-old female renal transplant patient undergoing surgery for acute appendicitis. Surgical management of double appendix is of practical importance to avoid serious medical and legal consequences.

Keywords: Double appendix, acute appendicitis, appendectomy

\section{|IIIIIIII| ÖZ}

Akut apandisit travmatik olmayan acil cerrahi gerektiren en sık patoloji olup apendikse ait duplikasyon nadir bir konjenital anomalidir ve genellikle laparotomi esnasında tesadüfen saptanır. Picoli'nin eşlik eden anomalileri olan bir kadın hastada ilk apendiks duplikasyonu olgusunu bildirdikten sonra sınırlı sayıda olgu bildirilmiştir. Bu çalışmada akut apandisit nedeniyle ameliyat ettiğimiz 56 yaşında böbrek transplantılı bir kadın hastada tespit edilen apendiks duplikasyonu olgusunu sunmak amaçlanmıştır. Apendiks duplikasyonunun cerrahi yönetimi ciddi medikal ve yasal sonuçlardan kaçınmak adına pratik öneme sahiptir.

Anahtar Kelimeler: Apendiks duplikasyonu, akut apandisit, apendektomi

\section{Introduction}

The vermiform appendix develops as a conical extension from the apex of the caecal diverticulum which arises from the antimesenteric border of the proximal part of the post arterial segment of the mid gut. ${ }^{1}$ After Picoli and colleagues reported the first case of appendix duplex in a female patient who presented with associated anomalies, limited number of cases has been reported so far. ${ }^{2}$ Recently published review reported the incidence of duplicated appendix ranging from $0.004 \%$ to $0.009 \% .^{3}$ In this study, we aimed to present a case of an appendix duplication which was diagnosed in a 56-yearold female renal transplant patient undergoing surgery for acute appendicitis.

\section{Case Report}

A 56-year-old female patient with a history of renal transplantation from 10 years ago was admitted to the emergency room due to fever, vomiting and abdominal pain that has been going on for 2 days. On the physical examination, there was defense and rebound in the suprapubic region and subsequently migrated the right lower quadrant. Body temperature was $3.8^{\circ} \mathrm{C}$ and all other hemodynamic parameters were in the normal range. In the laboratory study, the white blood cells was $17.750 \mathrm{~mm}^{3}$ and the other values were in the normal range. Abdominal tomography was compatible with acute appendicitis (Figure 1). As the patient experienced kidney transplantation with

Address for Correspondence/Yazışma Adresi: Ahmet Rencüzoğulları MD,

Çukurova University Faculty of Medicine, Department of General Surgery, Adana, Turkey

Phone: +90 5321798280 E-mail: rencuzdr@gmail.com ORCID ID: orcid.org/0000-0002-5993-9536

Received/Geliş Tarihi: 12.08.2018 Accepted/Kabul Tarihi: 04.09.2018 


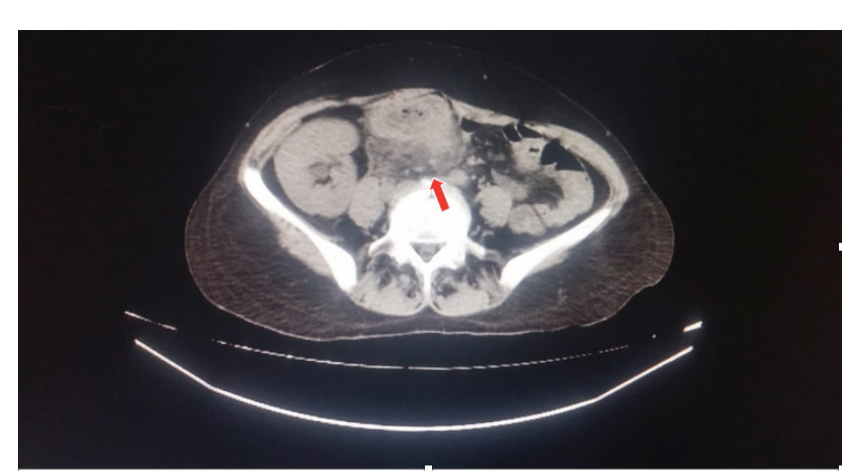

Figure 1. An inflamed bowel segment formed a mass of $2 \times 3 \mathrm{~cm}$ in size which mimicked a plastrone secondary to acute appendicitis

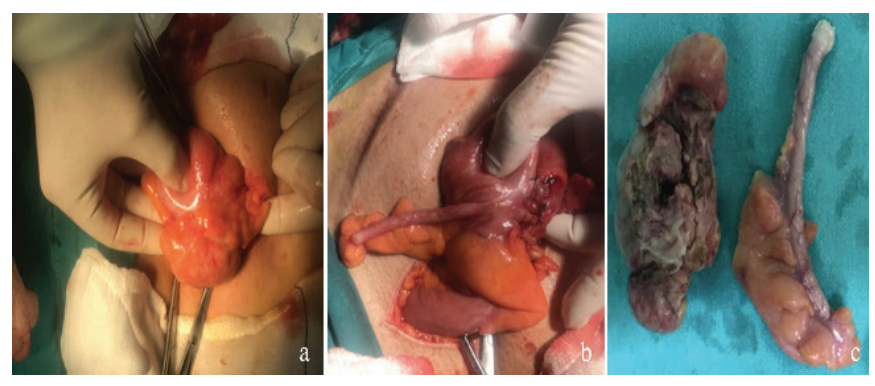

Figure 2. Macroscopic appearance of inflamed appendix (a), normal appendix (b) and pathologic specimen (c)

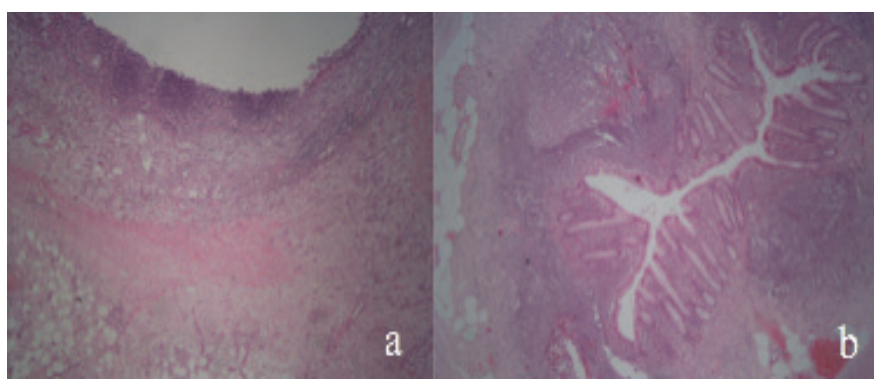

Figure 3. Microscopic view showing (H\&E, X100) mucosal erosion and inflammation indicating acute appendicitis (a) and appendix with lymphoid follicles (b) a right-oblique lumbar incision extending right lower quadrant, open surgical approach is preferred. During exploration, Type B2 appendix duplication, based on the Cave-Wallbridge classification ${ }^{5}$, was detected (Figure 2). The patient was examined for congenital malformation of other intra-abdominal organs, and no other malformation was identified. While one of the appendixes had the findings of acute inflammation, the other one had a normal appearance (Figure $3 \mathrm{a}$ and 3b). Appendectomy for both appendixes was performed. Histopathological examination of the surgical specimen confirmed the intraoperative findings of appendiceal duplication as well as findings of acute inflammation of the second appendix. On pathological examination, the appendixes measured $7 \times 4 \times 3.5 \mathrm{~cm}$ and $8 \times 3 \times 1 \mathrm{~cm}$. One of the appendixes was acute perforated appendicitis, periappendicitis and the other was appendix vermiformis. Microscopic images of both appendixes are shown in the Figure 1c. The patient had a full recovery without postoperative complications and was discharged on the postoperative day 4 .

\section{Discussion}

Although the normal embryogenesis of the appendix is known, the exact cause of appendiceal duplication has not been fully explained. In an attempt to explain the pathogenesis of duplication, Cave put forward two theories; (i) the persistence of a transient embryological structure and (ii) incidental appendiceal duplicity to a more general affection of the primitive midgut. ${ }^{4}$

Since preoperative radiological identification of duplication of appendix is difficult, computed tomography may be the best mode of imaging to identify a duplex appendix. ${ }^{3}$ The surgeons intraoperative attention and awareness are vital in terms of diagnosis. Macroscopic view and histopathological examination are substantially pathognomonic. The majority

Table 1. Cave-Wallbridge classification

Type A Single caecum with one appendix exhibiting partial duplication.

Type B Single caecum with two obviously separate appendixes.

B1 The two appendixes arise on either side of the ileocaecal valve in a B bird-like manner.

B2 In addition to a normal appendix arising from the caecum at the usual site, there is also a second, usually

B2 rudimentary, appendix arising from the caecum along the lines of the taenia at a varying distance from the first.

B3 The second appendix is located along the taenia of the hepatic flexure of the colon.

B4 The location of the second appendix is along the taenia of the splenic flexure of the colon.

Type C

Double caecum, each bearing its own appendix and associated with multiple duplication anomalies of the intestinal tract as well as the urinary tract. 
of duplicated appendixes is believed to be silent and only discovered when one of them becomes inflamed.

In 1936, Cave classified appendiceal duplication for the first time which was modified by Wallbridge in 1963 into three types; as shown in Table 1.,5

Appendix duplications are usually detected incidentally during surgery for acute appendicitis and it was identified in the same way in our case. As performed in our case, appendectomy for both appendixes is necessary for the correct evaluation of the clinical problems of patients with subsequent abdominal pain. We noticed that our patient had type B2 appendiceal duplication based on the CaveWallbridge classification. Most authors agree that Type B2 duplication may be the remnant of a "transient appendix" which appears during the sixth and seventh week of embryological development, the presence of which was first reported by Kelly and Hurdon. ${ }^{3,6}$ Although appendiceal duplication may be associated with other congenital abnormalities $^{4}$ any other anomalies were absent in our patient.

\section{Conclusion}

In conclusion, intraoperative detection of appendicular duplication is of great practical importance, as overlooking of this clinical scenario may lead to medical and legal issues. Surgeons, especially junior surgical residents, should be aware of the potential anatomical anomalies and malpositions of the vermiform appendix; careful inspection of the caecum should be performed to avoid potentially serious clinical and medicolegal consequences. Moreover, acute appendicitis should be considered as a part of differential diagnosis of acute right lower quadrant pain despite history of appendectomy.

\section{Ethics}

Informed Consent: Obtained from the patient that was mentioned in the manuscript.

Peer-review: Externally peer-reviewed.

\section{Author Contributions}

Surgical and Medical Practices: U.T., A.R., Concept: U.T., F.D., A.R., Design: U.T., F.D., A.R., Data Collection or Processing: U.T., F.D., A.R., Analysis or Interpretation: U.T., F.D., A.R., Literature Search: U.T., F.D., A.R., Writing: U.T., F.D., A.R.

Conflict of Interest: The authors have no conflicts of interest including relevant financial interests, activities, relationships, and affiliations.

Financial Disclosure: The authors declared that this study received no financial support.

\section{References}

1. Moore KL. Saunders. The developing human: clinically oriented embryology with student consult online access; 9th edition. 2011.

2. Khanna AK, Appendix Vermiformis Duplex. Postgrad Med J 1983;59:6970 .

3. Nageswaran H, Khan U, Hill F, Maw A. Appendiceal duplication: a comprehensive review of published cases and clinical recommendations. World J Surg 2018;42:574-558.

4. Cave AJ. Appendix vermiformis duplex. J Anat 1936;70:283-292.

5. Wallbridge PH. Double appendix. Br J Surg 1963;50:346-347. doi:10.1002/ bjs. 18005022124 .

6. Kelly HA, Hurdon E. Vermiform appendix and its diseases. Philadelphia; WB Saunders Co. 1905. 